\title{
The protein-sparing effect of carbohydrate
}

\section{Nitrogen retention of growing pigs in relation to diet}

\author{
BY M. F. FULLER AND R. M. J. CROFTS \\ Rowett Research Institute, Bucksburn, Aberdeen AB2 9SB
}

(Received 20 January 1977 - Accepted 5 April 1977)

1. Measurements were made of the losses of nitrogen in the faeces and urine of sixty pigs of approximately $33 \mathrm{~kg}$, given dietary regimens comprising twenty-nine combinations of fish four $(0-800 \mathrm{~g} / \mathrm{d})$ and maize starch $(0-1200 \mathrm{~g} / \mathrm{d})$.

2. The results were used to develop a generalized equation describing $\mathbf{N}$ retention as a joint function of $\mathrm{N}$ intake and starch intake.

3. The protein-sparing effect of starch was exerted in all circumstances. It was greatest when protein intake exceeded $220 \mathrm{~g} / \mathrm{d}$ but some effect persisted with protein-free diets. With a high protein supply, the increase in $\mathrm{N}$ retention per unit increase in dietary starch decreased from $36 \mathrm{mg} / \mathrm{g}$ with the first increment to $3 \mathrm{mg} / \mathrm{g}$ with the highest attainable starch intake.

4. From the generalized equation the relationships between net protein utilization and protein concentration and food intake could be described as continuous functions. The equations may be of use in comparing the protein values of diets measured under non-standardized conditions.

One of the difficulties of estimating nutrient requirements arises when the efficiency with which a nutrient is utilized is not constant. This difficulty seems to arise to some extent with every nutrient. In some instances it may be overcome for practical purposes by delineating a range over which a constant efficiency is a reasonable approximation. In studies of energy metabolism, for example, the convention has commonly been adopted of treating efficiency for maintenance and for growth as two constants, although this implies a distinct discontinuity at maintenance, whereas the over-all relationship may be better described by a single exponential equation (Blaxter \& Boyne, 1970) with a continuously diminishing efficiency.

This difficulty is particularly evident in estimating protein requirements, and it has long been realized that the efficiency of protein utilization is not determined simply by the amino acid composition of the protein but by the amount and composition of the diet in which the protein is supplied to the animal.

It has been recognized that there are, in the absence of vitamin and mineral deficiencies, three major dietary variables which jointly determine the efficiency of protein utilization: the quality of the protein, the amount of protein given and the amounts of lipid and carbohydrate, the non-protein energy, given with it.

Although these are the primary unconfounded variables, the effects on protein utilization of the amounts of protein and non-protein energy have usually been examined in terms of the variables derived from them: protein concentration (protein energy as a proportion of total energy) and daily food intake. Measurements of biological value (Bv), or of net protein utilization (NPU) are by convention, therefore, made at a constant protein concentration, commonly $0 \cdot 1$.

In more practical studies, there is a need to estimate the protein value of diets fed unaltered; in such instances a comparison of the protein quality of two diets can be made only if the effects on protein utilization of protein concentration and of food intake are known, so that appropriate correction to the results can be made.

Miller \& Payne (1961 a) suggested that NPU decreased as a linear function of dietary protein concentration, a view which was challenged by $\mathrm{Njaa}$ (1962) and by Morrison, 
Sabry, Gridgeman \& Campbell (1963) who showed that a semilogarithmic decrease gave a better fit to results at high protein concentrations.

Miller \& Payne $(1961 b)$ also examined the effects of total energy intake on protein utilization. They decided that the results were best described by two relationships, one with a generous energy supply, when NPU is a function only of protein quality and protein concentration, the other when energy is limiting. From their results they postulated an energy cost for protein accretion of $100 \mathrm{~kJ} / \mathrm{g}$. This estimate includes, in addition to the energy expended in protein accretion, the energy associated with a concomitant deposition of fat.

Dietary carbohydrate and fat also act as a stimulus to protein accretion in growing animals; this is their protein-sparing effect which has been thoroughly reviewed by Munro $(1951,1964)$. It is evident that the effect comprises at least three factors. First, as already mentioned, protein accretion requires energy both for the synthesis of peptide bonds, which, because of the continuous turnover of body protein, may greatly exceed those attributable to net protein accretion as well as for the many support processes of growth, inevitably associated with protein accretion. The total cost, according to a number of recent studies reviewed by Kielanowski (1976), amounts to $45-70 \mathrm{~kJ} / \mathrm{g}$ protein accretion.

Secondly, the greater the dilution of dietary protein by other sources of energy the less probable it is that amino acids will be deaminated. As the pathways of protein, carbohydrate and fat dissimilation converge in the tricarboxylic acid cycle, saturation of the cycle with residues arising from carbohydrate or fat will provide feedback inhibition of amino acid degradation.

The third factor includes several effects of carbohydrate largely or entirely attributable to the anabolic actions of insulin, released in response to carbohydrate absorption (Munro, 1964). This aspect is investigated in a following paper (Fuller, Weekes, Cadenhead \& Bruce, 1977).

The first two factors depend directly on the energy-yielding properties of carbohydrate and fat; the third factor does not involve the oxidation of the carbohydrate and fat but depends on their actions, direct or indirect, as regulators of hormone and enzyme activity.

All these contributors to the protein-sparing effects of carbohydrate and fat ensure that the efficiency with which growing animals utilize their dietary protein only approaches the maximum determined by the $\mathrm{BV}$ of the protein when very large amounts of non-protein energy are given. Conversely, the utilization of dietary protein diminishes with decreases in energy intake even while a considerable fat deposition continues.

Teleologically, it is clear why such an effect is necessary. Without it, fat would be deposited only when the energy supply exceeded that required for maintenance and protein synthesis; animals getting less energy than this would gain only lean tissue, whereas fat is the superior energy store for survival in any subsequent period of more severe undernutrition.

The interdependence of the protein and energy supplies in protein metabolism was summarized by Munro (1964): ' Under normal nutritional conditions, $N$ balance is improved by an increase in either energy intake or in protein intake. However, the beneficial effect of a rise in energy intake can be modified or prevented by an inadequate protein intake, and, conversely, an increased protein intake may not be fully effective because of insufficient energy in the diet'.

Prediction of the magnitude of these effects is important in estimating the amounts of nutrients necessary to support specified rates of weight gain or $\mathrm{N}$ retention. This experiment set out to develop a generalized quantitative description of the interaction between the intakes of protein and of non-protein energy by varying each over the widest possible range. It was felt important to use as variables protein and non-protein energy rather 


\section{Table 1. Composition of the dietary ingredients}

$\begin{array}{lccc} & \begin{array}{c}\text { Dry matter } \\ (\mathrm{g} / \mathrm{g})\end{array} & \begin{array}{c}\text { Nitrogen } \\ (\mathrm{g} / \mathrm{g})\end{array} & \begin{array}{c}\text { Energy } \\ (\mathrm{kJ} / \mathrm{g})\end{array} \\ \text { Fish flour } & \mathbf{0 . 9 1} & \mathbf{0 . 1 2 8 ^ { * }} & 18.6 \\ \text { Maize starch } & \mathbf{0 . 8 7} & 0.0006 & 15.0 \\ \text { Fish oil } & \text { nd } & 0.0007 & 39.4 \\ \text { Ethanol-extracted wood fibre } & \mathbf{0 . 9 3} & 0.0013 & \text { nd }\end{array}$

nd, Not determined.

* Containing $(\mathrm{mg} / \mathrm{g} \mathrm{N}$ ): asparagine 431 , threonine 200 , serine 256 , glutamine 625 , proline 219 , glycine 475 , alanine 337 , valine 256 , cystine 25 , methionine 156 (cystine and methionine values probably low due to hydrolysis), isoleucine 225 , leucine 313 , tyrosine 188 , phenylalanine 194 , lysine 400 , histidine 94 , arginine 363 , taurine 44, hydroxyproline 100 .

than the more common variables derived from them: protein concentration and food (or total energy) intake, not because the empirical description of the responses to diet might be any more precise, but because use of the unconfounded variables might lead to a clearer view of the nature of their interaction.

\section{EXPERIMENTAL}

Animals

Sixty-three Large White $\times$ Landrace pigs were allocated at random, two or three to each dietary regimen. All were castrated males weighing on average $30 \mathrm{~kg}$ at the start of the experiment (range $25-36 \mathrm{~kg}$ ): during the experiment some pigs gained weight and some lost weight according to their diet, and their average weight when the measurements were made was $33 \mathrm{~kg}$.

\section{Nutritional regimens}

Twenty-nine combinations of fish flour $(0-800 \mathrm{~g} / \mathrm{d})$ and maize starch $(0-1200 \mathrm{~g} / \mathrm{d})$ formed the basis of the regimens. The composition of the fish flour is given in Table 1 . The lipid content of the fish flour was $30 \mathrm{~g} / \mathrm{kg}$; to provide a constant lipid concentration in all diets fish oil was added at the rate of $30 \mathrm{~g} / \mathrm{kg}$ maize starch. All diets included a complete vitamin and mineral mixture and to ensure continued faeces production ethanol-extracted wood fibre $(30 \mathrm{~g} / \mathrm{kg})$ was added to all diets. The intakes of protein and starch achieved for the different regimens are shown in Fig. 1.

\section{Experimental procedure}

Each pig was confined in a metabolism cage for several days before the experimental regimen was introduced. Each diet was fed for $18 \mathrm{~d}$; for the last $11 \mathrm{~d}$ all faeces were collected, and urine was collected for two consecutive periods of $5 \mathrm{~d}$ and $6 \mathrm{~d}$.

The animals were fed twice daily. Any spilled food was added to the next meal. Thirteen pigs were unable to eat their full ration and the residues were dried and weighed to allow calculation of their actual nutrient intakes.

\section{RESULTS AND DISCUSSION}

\section{Body-weight changes}

On their various nutritional regimens some animals gained weight and others lost weight. Over such a short period these weight changes cannot be considered reliable estimates of the long-term effects of the regimens on growth, but to minimize the effect of divergencies of body-weight on the expression of the results, values for the measured variables have 


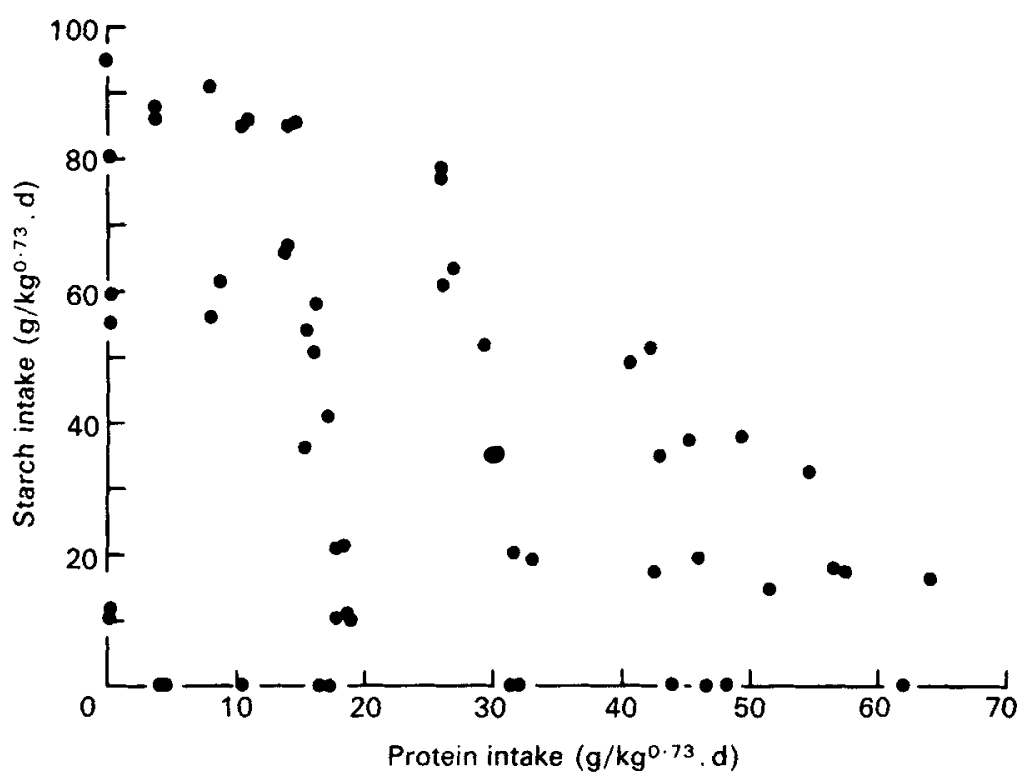

Fig. 1. The amounts of starch and protein $\left(\mathrm{g} / \mathrm{kg}^{0.73}\right.$ per d) eaten by pigs. For details of diets, see p. 481 . Each point represents the value for one animal.

been divided by the mean metabolic body-weight $\left(W^{0.73}\right)$ of the animal during the period of the measurements.

\section{Digestibility of $N$}

The over-all mean apparent digestibility of $\mathrm{N}$ was 0.96 . To examine the effects of $\mathrm{N}$ intake and starch on $N$ digestibility a joint regression was calculated in which faecal $N\left(F^{\prime}\right.$; $\mathrm{g} / \mathrm{kg}^{0.73}$ per d) was expressed as a joint function of $\mathrm{N}$ intake $\left(\mathrm{I}^{\prime} ; \mathrm{g} / \mathrm{kg}^{0.73}\right.$ per d) and of starch intake $\left(\mathrm{S}^{\prime} ; \mathrm{g} / \mathrm{kg}^{0.73}\right.$ per $\left.\mathrm{d}\right)$ :

$$
\begin{gathered}
F^{\prime}=0.020+0.0125 I^{\prime}+0.0034\left(I^{\prime}\right)^{2}+0.00072 S^{\prime} \quad(\text { residual SD }(\mathrm{RSD}) \pm 0.074) \\
( \pm 0.012) \quad( \pm 0.0012) \quad( \pm 0.00034)
\end{gathered}
$$

This equation accounted for $72.7 \%$ of the variance in faecal $\mathrm{N}$. The equation shows that the faecal loss of $\mathrm{N}$ varied with the $\mathrm{N}$ intake, and was only slightly increased by the starch intake.

\section{Urinary $N$ excretion}

Examination of the relationship between urinary $\mathrm{N}$ and $\mathrm{N}$ intake showed that urinary $\mathrm{N}$ was most reduced by additions of starch when large amounts of $\mathrm{N}$ were given, but that some protein-sparing effect persisted even at zero $\mathrm{N}$ intake. This finding is shown in Fig. 2 where, for clarity, results are given only for pigs receiving no starch or high amounts of starch $\left(60-90 \mathrm{~g} / \mathrm{kg}^{0.73}\right.$ per d). With starch-free diets, urinary $\mathrm{N}\left(\mathrm{U}^{\prime} ; \mathrm{g} / \mathrm{kg}^{0.73}\right.$ per d). appeared to increase linearly with $\mathrm{N}$ intake $\left(\mathrm{I}^{\prime} ; \mathrm{g} / \mathrm{kg}^{0.73}\right.$ per $\left.\mathrm{d}\right)$; a preliminary approximation of this relationship was:

$$
\mathrm{U}^{\prime}=0.5+0.77 \mathrm{I}^{\prime} \text {. }
$$

The reduction of urinary $\mathrm{N}$ in response to a high level of starch approached a maximum of approximately $-1.3 \mathrm{~g} / \mathrm{kg}^{0.73}$ per $\mathrm{d}$ at $\mathrm{N}$ intakes of $>3 \mathrm{~g} / \mathrm{kg}^{0.73}$ per $\mathrm{d}$, and the response to starch appeared to vanish at $\mathrm{N}$ intakes of approximately $-0.4 \mathrm{~g} / \mathrm{kg}^{0.73}$ per $\mathrm{d}$. This relationship seemed to be best described by an exponential relationship of the form:

$$
\Delta U^{\prime}=-1 \cdot 3\left(1-e^{-k\left(r^{\prime}+0 \cdot 4^{\prime}\right.}\right) \text {. }
$$




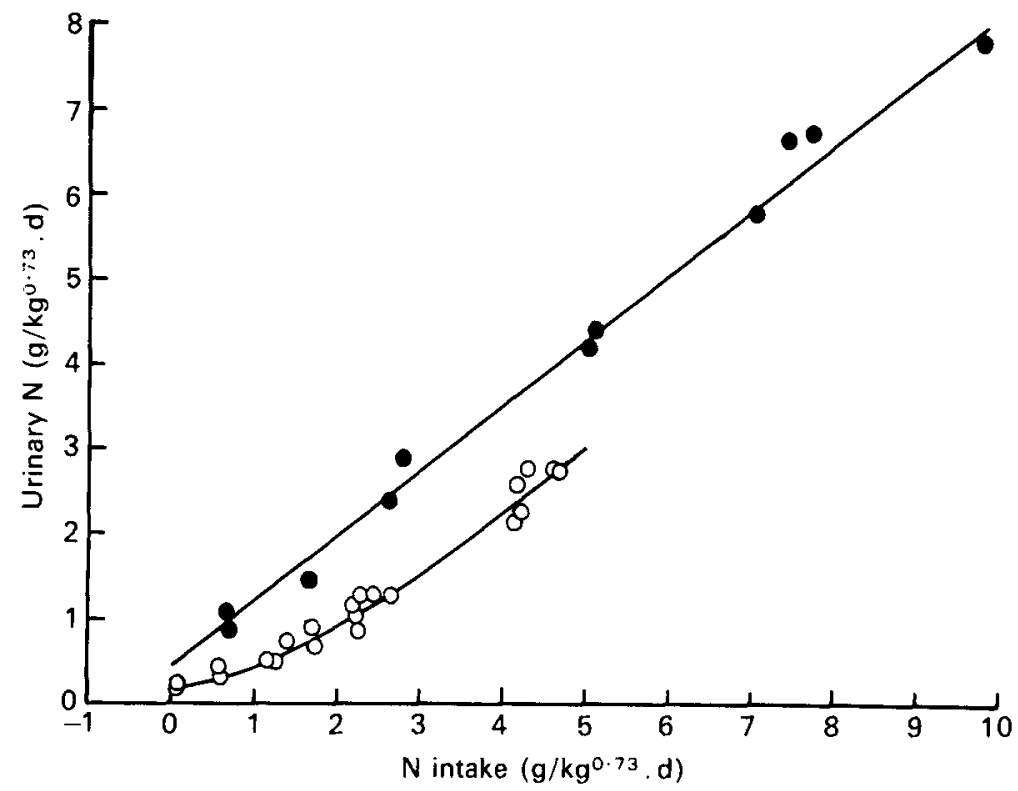

Fig. 2. The relationship between urinary nitrogen excretion $\left(\mathrm{g} / \mathrm{kg}^{0.73}\right.$ per d) and $\mathrm{N}$ intake $\left(\mathrm{g} / \mathrm{kg}^{0.79}\right.$ per d) for animals given diets containing no starch (O) or high amounts of starch $\left(60-90 \mathrm{~g} / \mathrm{kg}^{0.78}\right.$ per d) (O). For details of diets, see p. 481 . Each point represents the value for one animal.

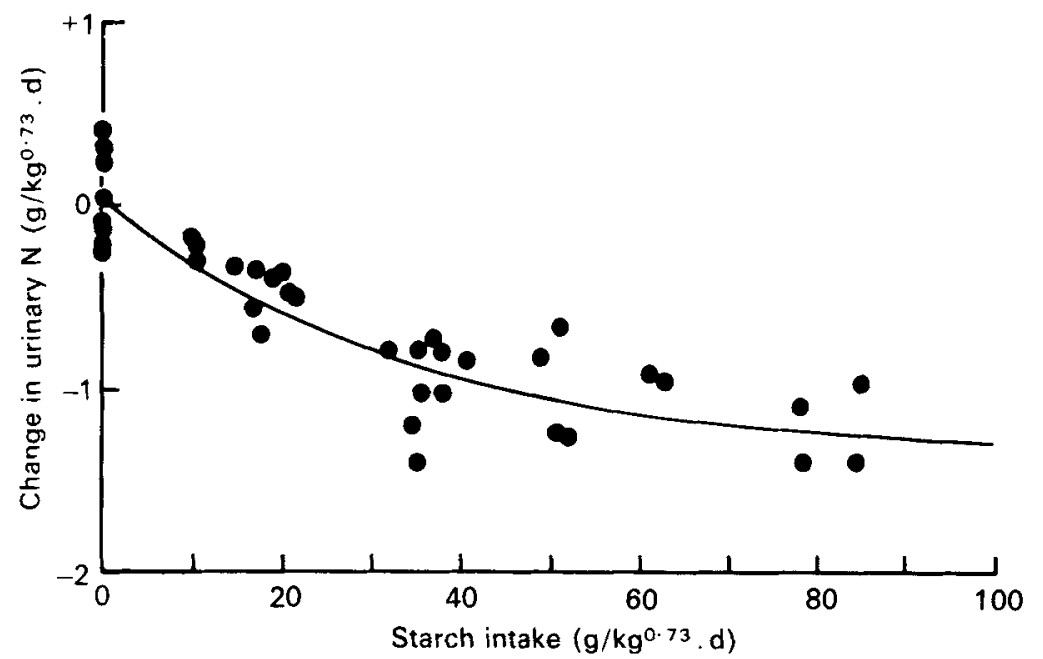

Fig. 3. The change in urinary nitrogen excretion $\left(\mathrm{g} / \mathrm{kg}^{0.78}\right.$ per $\left.\mathrm{d}\right)$ with increasing starch intakes $\left(\mathrm{g} / \mathrm{kg}^{0.73}\right.$ per d) for pigs given high amounts of dietary protein $\left(>3 \mathrm{~g} \mathrm{~N} / \mathrm{kg}^{0.73}\right.$ per d). For details of diets, see p. 481. Each point represents the value for one animal.

where $\Delta \mathrm{U}^{\prime}$ is the reduction in urinary $\mathrm{N}\left(\mathrm{g} / \mathrm{kg}^{0.73}\right.$ per d) and $k$ is a constant. Combining this with equation (2) gave the approximate relationship between urinary $N$ and $N$ intake for high starch intakes as:

$$
\mathrm{U}^{\prime}=0.5+0.77 \mathrm{I}^{\prime}-1 \cdot 3\left(1-e^{-k\left(\mathrm{I}^{\prime}+0.4\right)}\right) \text {. }
$$

A preliminary estimate of $k$ was $0 \cdot 8$.

The response of urinary $\mathrm{N}$ to increasing starch intake (including the intermediate intakes 


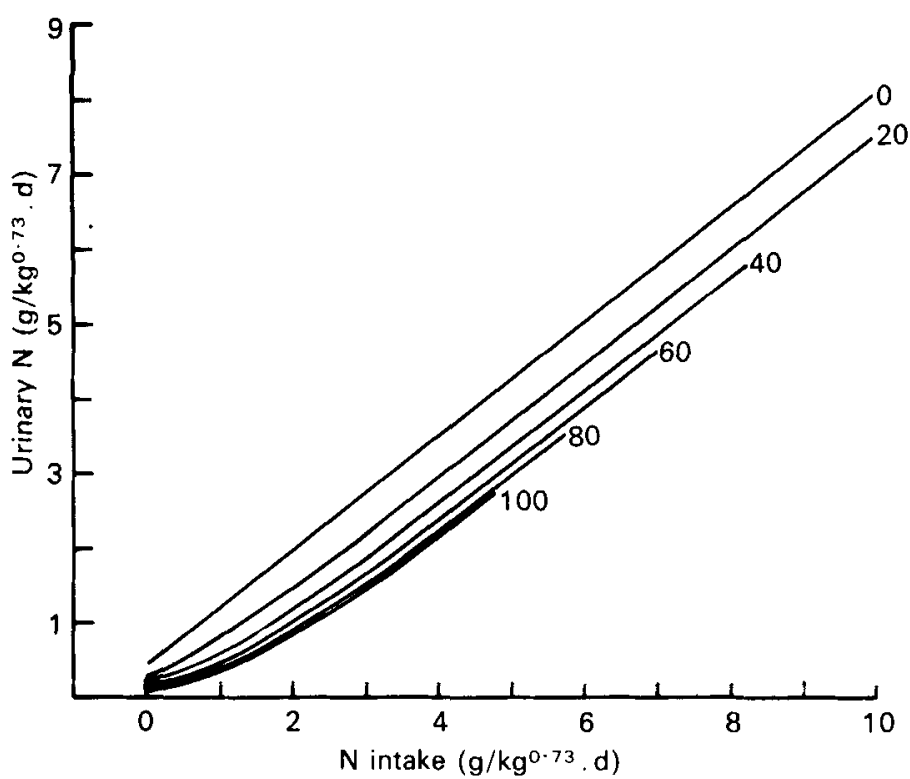

Fig. 4. The relationship, from the equation ' $\mathrm{U}^{\prime}=0.47+0.771^{\prime}-1.54\left(1-e^{-0.0230 \mathrm{~s}^{\prime}}\right)(1-0.805$ $e^{-0.747 \mathrm{I}^{\prime}}$ ) (equation (8); for derivation, see pp. 482-484), between urinary nitrogen excretion $\left(\mathrm{U}^{\prime}: \mathrm{g} / \mathrm{kg}^{0.73}\right.$ per d) and $\mathrm{N}$ intake $\left(\mathrm{I}^{\prime}: \mathrm{g} / \mathrm{kg}^{0.73}\right.$ per d) for pigs given diets containing starch at various rates $\left(S^{\prime}: \mathrm{g} / \mathrm{kg}^{0.73}\right.$ per d). For details of diets, see p. 481 .

not shown in Fig. 2) at $\mathrm{N}$ intakes greater than $3 \mathrm{~g} / \mathrm{kg}^{0.73}$ per $\mathrm{d}$ is shown in Fig. 3. There is no indication from this of any reversal of the protein-sparing effect at high starch intakes; this relationship also appeared to be exponential, described as a first approximation by:

$$
\Delta \mathrm{U}^{\prime}=-1.5\left(1-e^{-0.02 \mathrm{~s}^{\prime}}\right),
$$

where $S^{\prime}$ is the starch intake $\left(\mathrm{g} / \mathrm{kg}^{0.73}\right.$ per $\left.\mathrm{d}\right)$.

Combining this approximation with equation (4), -1.5 replaces $-1 \cdot 3$, giving an equation approximately describing all the results:

$$
\mathrm{U}^{\prime}=0.5+0.77 \mathrm{I}^{\prime}-1.5\left(1-e^{-0.02 \mathrm{~s}^{\prime}}\right)\left(1-e^{-0.8^{\prime} \mathrm{I}^{\prime}+0.4}\right),
$$

where $\mathrm{I}^{\prime}$ is $\mathrm{N}$ intake $\left(\mathrm{g} / \mathrm{kg}^{0.73}\right.$ per $\left.\mathrm{d}\right)$. This equation provided a first approximation of each of the six constants. A 'least-squares' solution of this equation fitted to all sixty observations was then obtained by a process of successive iteration to give:

$$
\mathrm{U}^{\prime}=0.25+0.77\left(\mathrm{I}^{\prime}+0.29\right)-1.54\left(1-e^{-0.02398}\right)\left(1-e^{-0.747 \mathrm{I}^{\prime}+0.28}\right)(\mathrm{RSD} 0.283) \text {. }
$$

This equation accounted for $98.5 \%$ of the variance of urinary $\mathrm{N}$.

The significance of the term 0.29 is not immediately obvious. Perhaps it is that at zero $\mathrm{N}$ intake part of the flux of amino acids arising from body protein degradation enters a system upon which starch can exert its effect of inhibiting deamination; indeed, this is the original context of the term 'protein-sparing'. The magnitude of this flux is indicated by the $\mathrm{N}$ input, $\mathrm{I}^{\prime}=0 \cdot 29$, corresponding to $23 \mathrm{~g}$ of protein per pig daily. The maximum possible extent of the protein-sparing effect under these conditions is to spare all the amino acids entering this system, i.e. $0.29 \mathrm{~g} \mathrm{~N} / \mathrm{kg}^{0.73}$ per d. Evaluation of the proteinsparing term of equation (8), $-1.54\left(1-e^{-0.0239 \mathrm{~s}^{\prime}}\right)\left(1-0.805 e^{-0.747 \mathrm{I}^{\prime}}\right)$, at $\mathrm{I}^{\prime}=0$ gives a maximum protein-sparing effect of $0.30 \mathrm{~g}$, indicating a complete sparing of this component of protein catabolism. This does not suggest, however, that all the fasting $\mathrm{N}$ loss is abolished by starch; at the maximum attainable starch intake $\left(100 \mathrm{~g} / \mathrm{kg}^{0.73}\right.$ per d) the reduction in 


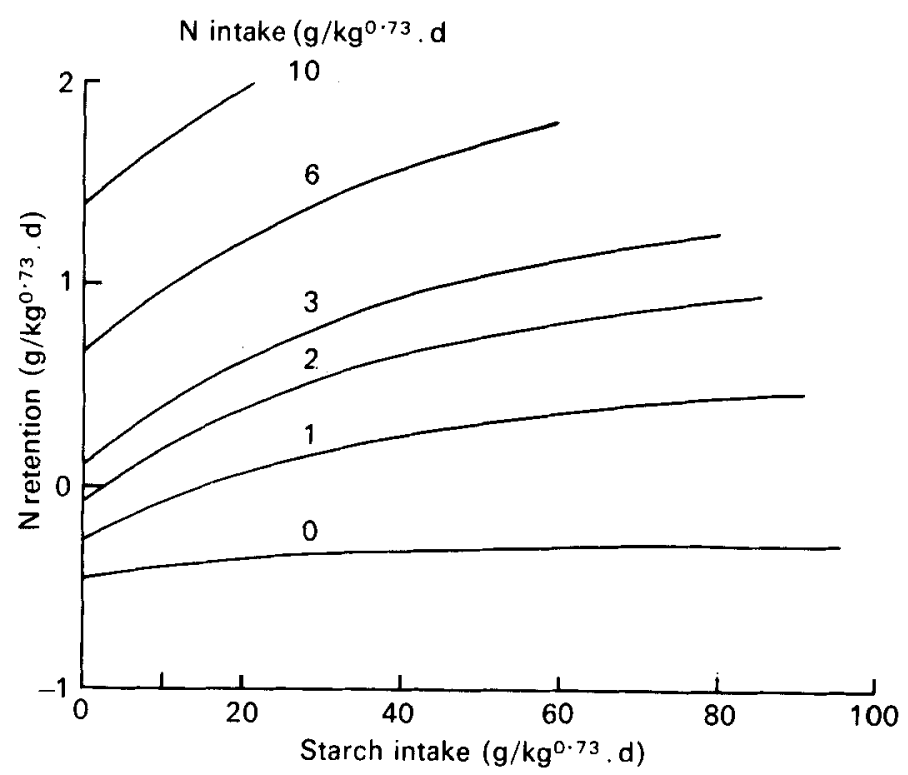

Fig. 5. The relationship, from the equation $R^{\prime}=-0.43+0.182 I^{\prime}+1.52\left(1-e^{-0.0236} \mathrm{~s}^{\prime}\right)(1-0.886$ $e^{-0.675 \mathrm{I}^{\prime}}$ ) (equation (9); for derivation, see pp. 482-485), between nitrogen retention $\left(\mathbf{R}^{\prime}: \mathbf{g} / \mathbf{k g}^{0.73}\right.$ per d) and starch intake $\left(S^{\prime}: \mathrm{g} / \mathrm{kg}^{0.73}\right.$ per d) for pigs given various daily intakes of $\mathrm{N}\left(\mathrm{I}^{\prime}: \mathrm{g} / \mathrm{kg}^{0.73}\right.$ per d) as fish flour. For details of diets, see p. 481 .

urinary $\mathrm{N}$ excietion was $0.27 \mathrm{~g} / \mathrm{kg}^{0.73}$ per $\mathrm{d}$, or $60 \%$ of the fasting $\mathrm{N}$ loss. This value is very similar to those found by Wimmer (1911) and by Rosenthal \& Allison (1956) in dogs given high amounts of starch. Their estimates of the maximum proportion of the fasting $N$ loss which could be spared by carbohydrate were 55 and $65 \%$ respectively. Equation (7) may be re-written:

$$
\mathrm{U}^{\prime}=0.47+0.77 \mathrm{I}^{\prime}-1.54\left(1-e^{-0.0239 \mathrm{~s}^{\prime}}\right)\left(1-0.805 e^{-0.747 \mathrm{I}^{\prime}}\right) \text {. }
$$

Fig. 4 depicts the relationship described by equation (8) between urinary $\mathrm{N}$ and $\mathrm{N}$ intake at each of six rates of starch intake.

\section{$N$ retention}

Individual values of $N$ retention $\left(R^{\prime} ; g / k^{0.73}\right.$ per d) were related to $N$ intake and starch intake by a generalized equation derived in the same way as equation (8). The fitted equation was:

$$
\left.\mathrm{R}^{\prime}=-0.43+0.182 \mathrm{I}^{\prime}+1.52\left(1-e^{-0.0236 \mathrm{~s}^{\prime}}\right)\left(1-0.886 e^{-0.675 \mathrm{r}^{\prime}}\right) \text { (RSD } 0.281\right) \text {. }
$$

This equation accounted for $85.4 \%$ of the variance in $\mathrm{N}$ retention. Estimates of $\mathrm{N}$ retention in relation to $\mathrm{N}$ and starch intakes are shown in Fig. 5 .

\section{The protein-sparing effect of starch}

According to equation (9) it is clear that the magnitude of the response of $\mathrm{N}$ retention to an increment of starch, the protein-sparing effect, depends on both the amount of starch given and the protein supplied. Its magnitude in relation to these dietary variables has been calculated by differentiation of equation (9) with respect to $S^{\prime}$ :

$$
\frac{\mathrm{dR}^{\prime}}{\mathrm{dS}^{\prime}}=0.036 e^{-0.0236 \mathrm{~s}^{\prime}}\left(1-0.886 e^{-0.675 \mathrm{I}^{\prime}}\right) \text {. }
$$


Table 2. The protein-sparing effect of dietary starch (increase in nitrogen retention per unit increment of starch, $\left.d R\right|^{\prime} d S^{\prime} \mathrm{mg} / \mathrm{g}$ ) in relation to the intakes of protein and starch*

The values are derived from the equation:

\begin{tabular}{|c|c|c|c|c|c|c|}
\hline \multirow[b]{2}{*}{$\begin{array}{c}\text { Starch intake }\left(\mathrm{g} / \mathrm{kg}^{0.73} \text { per } \mathrm{d}\right) \\
\mathrm{N} \text { intake } \\
\left(\mathrm{g} / \mathrm{kg}^{0.73} \text { per } \mathrm{d}\right)\end{array}$} & \multicolumn{5}{|c|}{$\begin{array}{l}\text { Protein-sparing effect } \\
\text { (mg N/g starch) }\end{array}$} & \multirow[b]{2}{*}{100} \\
\hline & $\ldots$ & 20 & 40 & 60 & 80 & \\
\hline $\begin{array}{l}0 \\
2 \\
9\end{array}$ & $\begin{array}{r}4 \cdot 1 \\
27 \cdot 7 \\
35 \cdot 9\end{array}$ & $\begin{array}{r}2 \cdot 6 \\
17 \cdot 3 \\
22 \cdot 4\end{array}$ & $\begin{array}{r}1 \cdot 6 \\
10 \cdot 8 \\
14 \cdot 0\end{array}$ & $\begin{array}{l}1 \cdot 0 \\
6 \cdot 7 \\
8 \cdot 7\end{array}$ & $\begin{array}{l}0 \cdot 6 \\
4 \cdot 2 \\
5 \cdot 4\end{array}$ & $\begin{array}{l}0.4 \\
2 \cdot 6 \\
3 \cdot 4\end{array}$ \\
\hline
\end{tabular}

Values of this function are given in Table 2 for various combinations of dietary protein and starch.

It is clear that with protein-free diets, the protein-sparing effect, though still discernible is small; with increasing protein supply the effect becomes rapidly larger, as was shown by Munro \& Naismith (1953) and by Rosenthal \& Allison (1956). The present results suggest that the effect does not increase in direct proportion to the protein supply; the increase of $\mathrm{N}$ intake from 2 to $9 \mathrm{~g} / \mathrm{kg}^{0 \cdot 73}$ per d produced only a small further increase in the protein-sparing effect.

Concerning the form of the relationship of $\mathrm{N}$ retention to carbohydrate intake, Munro (1964) examined the results of experiments in which carbohydrate had been given at more than one level and concluded that 'it would appear that the degree of $\mathrm{N}$ retention was approximately proportional to the energy added'. The present results suggest a curvilinear response to starch, expressed in the equations by an exponential term, by which the proteinsparing effect diminishes at high intakes of carbohydrate (see Table 2). This effect is only apparent, however, when all the results are considered together; smaller portions of the matrix could te described adequately by linear relationships, and it is likely that this is the cause of the disparity of view. It is also possible that the curvature is less pronounced in adults wisere rates of $\mathrm{N}$ retention are inherently lower than in growing animals. Certainly, for growing animals, there is no real conflict of opinion. For exampie, in the experiment of Munro \& Naismith (1953) where the measurements with the diet containing protein were at approximately $\mathrm{N}$ equilibrium, our equation (9) predicts a parallel response in which the departure from linearity is barely perceptible.

Other experiments in the literature, covering a wider range of energy intakes and including higher rates of $\mathrm{N}$ retention, such as those of Terroine \& Mahler-Mendler (1927) with pigs, also indicate a diminished response to carbohydrate given at high levels.

\section{Estimation of endogenous urinary $N$ and of metabolic faecal $N$}

Direct observations were made with four pigs in the experiment given protein-free diets at rates between 55 and $95 \mathrm{~g} / \mathrm{kg}^{0.73}$ per $\mathrm{d}$. Their mean urinary $\mathrm{N}$ output was $0.16 \mathrm{~g} / \mathrm{kg}^{0.73}$ per $d$ and their mean faecal $N$ output was $0.06 \mathrm{~g} / \mathrm{kg}^{0.73}$ per $d$. For the calculation of NPU the combined urinary and faecal losses of pigs on a protein-free diet have therefore been taken as $0.22 \mathrm{~g} / \mathrm{kg}^{0.73}$ per $\mathrm{d}$. 


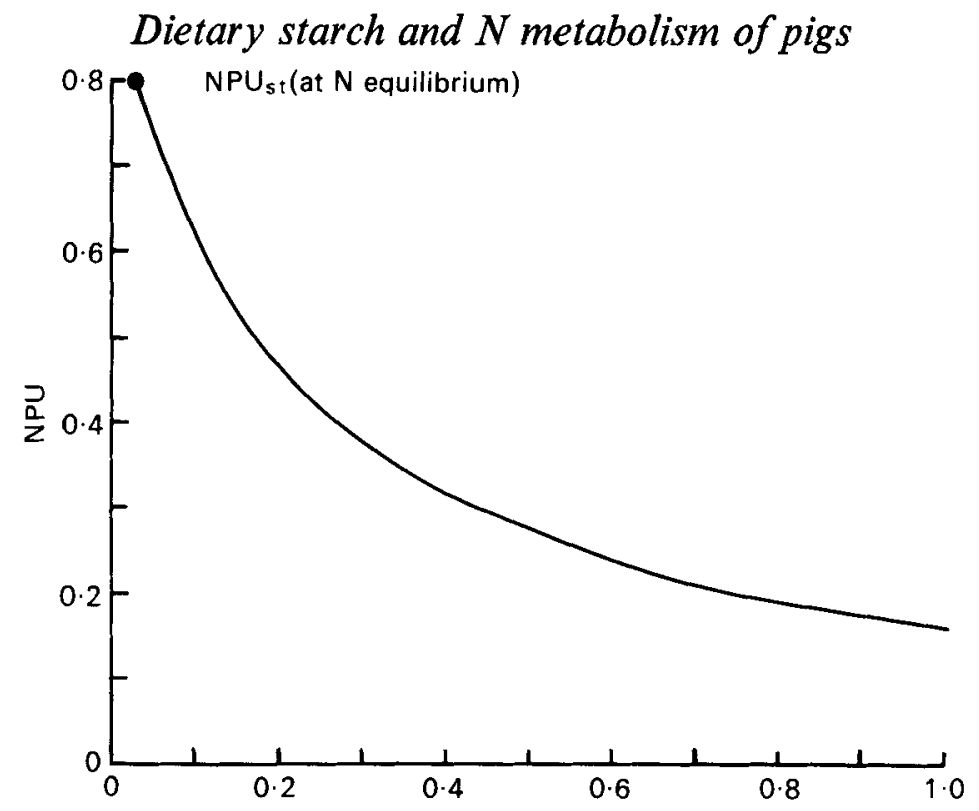

Protein concentration (protein energy as a proportion of total energy)

Fig. 6. The relationship between net protein utilization (NPU) and dietary protein concentration (protein energy as a proportion of total energy) for pigs with a daily food intake of $120 \mathrm{~g} / \mathrm{kg}^{0.73}$. Derived from the equation: $R^{\prime}=-0.43+0.182 I^{\prime}+1.52\left(1-e^{-0.286} \mathrm{~S}^{\prime}\right)\left(1-0.886 e^{-0.875 I^{\prime}}\right)$ where $\mathrm{R}^{\prime}=\mathrm{N}$ retention $\left(\mathrm{g} / \mathrm{kg}^{0.73}\right.$ per $\left.\mathrm{d}\right), \mathrm{I}^{\prime}=\mathrm{N}$ intake $\left(\mathrm{g} / \mathrm{kg}^{0.73}\right.$ per d) and $\mathrm{S}^{\prime}=$ starch intake $\left(\mathrm{g} / \mathrm{kg}^{0.73}\right.$ per d) (equation (9); for derivation, see pp. 482-485) and from the observed faecal and urinary $\mathrm{N}$ losses of pigs on protein-free diets (for details, see p. 486 ).

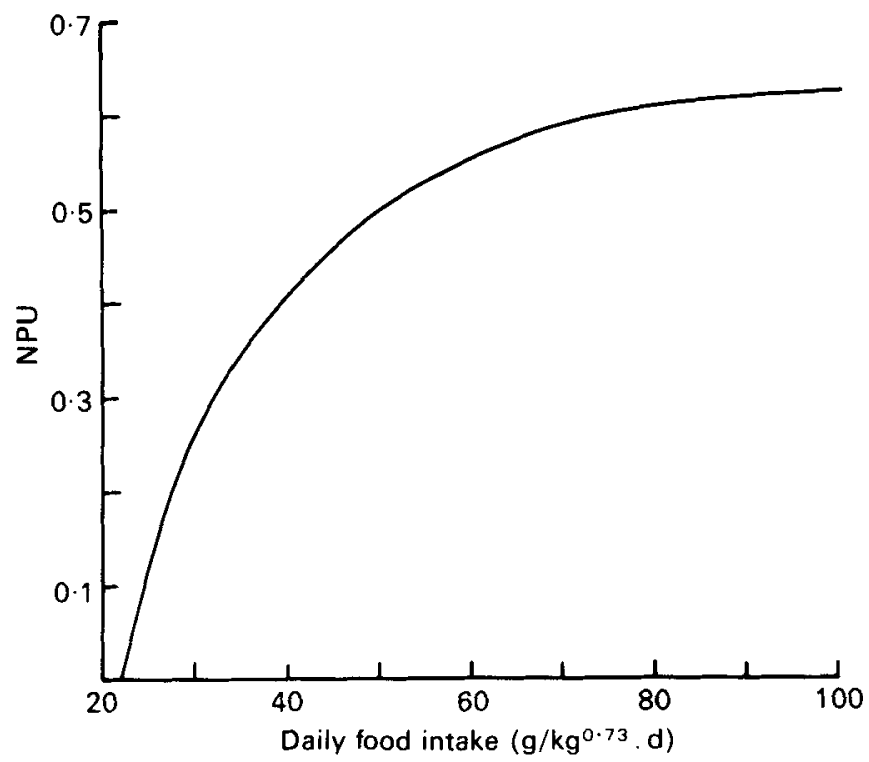

Fig. 7. The relationship between net protein utilization (NPU) and daily food intake $\left(\mathrm{g} / \mathrm{kg}^{0.73}\right.$ per d) for pigs given a diet with a protein concentration (protein energy as a proportion of total energy) of $0 \cdot 10$. Derived from the equation: $R^{\prime}=-0.43+0.182 I^{\prime}+1.52\left(1-e^{-0.02368^{\prime}}\right)\left(1-0.886 e^{-0.675 I^{\prime}}\right)$ where $R^{\prime}=N$ retention $\left(g / \mathrm{kg}^{0.73}\right.$ per d), $\mathrm{I}^{\prime}=\mathrm{N}$ intake $\left(\mathrm{g} / \mathrm{kg}^{0.73}\right.$ per d) and $\mathrm{S}^{\prime}=$ starch intake $\left(\mathrm{g} / \mathrm{kg}^{0.73}\right.$ per d) (equation (9); for derivation, see pp. 482-485). 


\section{Prediction by the equation of the effects of protein concentration on the utilization of protein}

It is clear from equation (9) that increasing protein concentration (protein energy as a proportion of total energy) has two opposing effects on $N$ retention: (1) to increase it by providing more dietary $N$; (2) to reduce it by providing less non-protein energy. Fig. 6 shows the effects on NPU of varying protein concentration from 0 to 1.0 with a total food intake of $120 \mathrm{~g} / \mathrm{kg}^{0.73}$ per d. Our results agree with $\mathrm{Njaa}$ (1962) and with Morrison et al. (1963) in showing that NPU did not decrease to zero as protein concentration approached 1.0 , but tended to level off, decreasing to 0.17 when protein concentration was 1.0 .

\section{NPU in relation to total food intake}

By inserting into equation (9) increasing values of the terms $I^{\prime}$ and $S^{\prime}$ (N intake and starch intake respectively) which are in a constant ratio depending on the protein concentration of the diet, the effect of increasing food intake on NPU may be predicted. Fig. 7 shows the effect on NPU of increasing the intake of a diet with a protein concentration of $0 \cdot 10$. These calculations show the reduction in NPU with severe energy restriction described by Rao \& Morrison (1966) and by Miller \& Payne (1961 b), and the relative insensitivity of NPU to food intake greater than $70 \mathrm{~g} / \mathrm{kg}^{0.73}$ per d. Miller \& Payne $(1961 b)$ regarded these as two separate ranges with a different equation to describe NPU in each. The derivation of the results in Fig. 7 from equation (9) shows that such treatment is not necessary, and that the results may be described as a continuous function of food intake.

\section{Limitations to the prediction of protein utilization}

It is clear that in addition to the dietary factors already discussed there are animal factors which affect protein utilization. These include genotype, sex, age and nutritional history. It is therefore difficult to see how the prediction of protein utilization as a function of diet can be made any more precise without taking into account these factors and their interactions as well as those relating to diet.

We wish to thank Mr G. M. Mackintosh for his assistance with the balance experiments, and the Analytical staff of the Institute for the chemical determinations. We are grateful to $\mathrm{Mr} \mathrm{A}$. W. Boyne for his advice on statistical techniques.

\section{REFERENCES}

Blaxter, K. L. \& Boyne, A. W. (1970). Publs Eur. Ass. Anim. Prod. no. 13, p. 9.

Fuller, M. F., Weekes, T. E. C., Cadenhead, A. \& Bruce, J. B. (1977). Br. J. Nutr. 38, 489.

Kielanowski, J. (1976). Publs Eur. Ass. Anim. Prod. no. 16, p. 207.

Miller, D. S. \& Payne, P. R. (1961a). Br. J. Nutr. 15, 11.

Miller, D. S. \& Payne, P. R. (1961 b). J. Nutr. 75, 225.

Morrison, A. B., Sabry, Z. I., Gridgeman, N. T. \& Campbell, J. A. (1963). Can. J. Biochem. Physiol. 41, 275.

Munro, H. N. (1951). Physiol. Rev. 31, 449.

Munro, H. N. (1964). In Mammalian Protein Metabolism, vol. 1, p. 381 [H. N. Munro and J. B. Allison, editors]. London: Academic Press.

Munro, H. N. \& Naismith, D. J. (1953). Biochem. J. 54, 191.

Njaa, L. R. (1962). Br. J. Nutr. 16, 185 .

Rao, M. N. \& Morrison, A. B. (1966). Can. J. Biochem. 44, 1365.

Rosenthal, H. L. \& Allison, J. B. (1956). J. agric. Fd Chem. 4, 792.

Terroine, E. F. \& Mahler-Mendler, A. M. (1927). Archs int, physiol. 28, 125.

Wimmer, M. (1911). Z. Biol. 57, 185. 